\title{
Peran Stakeholder dalam Komodifikasi Tradisi Perkawinan Hindu pada Paket Wisata Weeding di Kawasan Wisata
}

\author{
I Ketut Arta Widana \\ Program Studi Industri Perjalanan Fakultas Dharma Duta \\ IHDN Denpasar \\ anadiwatra@yahoo.co.id
}

\begin{abstract}
The development of cultural tourism has made any cultural products, profane and sacred, become comodity. The process of commotitisation is due to the need of many stakeholders in achieving the goal. The stakeholders playing important roles in the process of commoditisation according to the concept of "key actors" in tourism are government, local people, the tourists, media, industry, and the non-government organization. The commoditisation of traditional Hindu wedding in Ubud Tourism Resort (kawasan Wisata Ubud) is enabled by the meet of tourists motivation as the consummers and the other stakeholders as the supplier. The irrational motivation of the tourists to experience the autenticity with high buying power has made the tourism system in the hosts' side fulfil the tourists expectation for the sake of material achievement. Government has made restriction in conducting the traditional wedding to the tourists that made the wedding organizer respect the local tradition and socialize the restriction through the promotion website they have. But commoditisation can not be avoided since the locals don't mind to serve their tradition as a tourist product to purchase in the secular industry.
\end{abstract}

Keywords: commoditisation, stakeholders, tradition.

\section{Pendahuluan}

Pariwisata masal sudah berkembang pada saat awal pertumbuhannya di berbagai destinasi wisata yang menjadi tuan rumah wisatawan yang berasal dari negara-negara maju. Karakteristik kedatangan wisatawan yang berjumlah besar dengan perilaku yang konsumtif dan tidak ramah lingkungan sudah membawa berbagai dampak. Dampak positif yang selalu dibawa oleh kedatangan wisatawan adalah tumbuhnya perekonomian masyarakat tuan rumah akibat adanya pengeluaran yang dilakukan oleh wisatawan. Dampak positif dari wisatawan masal ini adalah jumlah penggunaan atau konsumsi yang massive pula yang membawa dampak pada pencemaran lingkungan, dan alih fungsi lahan untuk sarana akomodasi. Aktivitas wisatawan masal ini biasanya adalah mengunjungi pantai, berbelanja, mengunjungi daya tarik wisata yang sudah terkenal, serta menghabiskan waktu pada tempat-tempat hiburan malam. Secara sosial pun, aktivitas wisatawan ini digolongkan tidak bertanggungjawab sosial.

Kejenuhan pariwisata masal pada wisatawan asal negara maju menimbulkan permintaan baru, terutama dalam hal aktivitas. Aktivitas wisatawan mulai bergeser ke pedalaman untuk mendapatkan pengalaman baru tentang budaya destinasi setempat. Pariwisata budaya, kemudian, berkembang untuk memenuhi permintaan pasar wisatawan ini. Akibatnya adalah terjadinya pemanfaatan unsur-unsur budaya sebagai produk pariwisata untuk menarik minat kedatangan wisatawan. Pemanfaatan unsur unsur budaya Bali tersebut meliputi kesenian tradisi, adat-istiadat, serta ritual pada sistem religi. Motivasi wisatawan yang semakin dinamis sepertinya tidak berhenti pada berkunjung dan melihat-lihat tetapi juga mengalami hal-hal yang tidak mereka alami di negaranya. Pemanfaatan potensi budaya lokal pun sampai menyentuh sisi-sisi sakral yang akhirnya terkomodifikasi untuk pemenuhan minat pasar.

Beberapa wisatawan datang bahkan dengan minat khusus seperti minat untuk melakukan wisata spiritual melukat, melakukan upacara perkawinan dengan adat Bali, melakukan ritual penyembuhan dengan mengunjungi Balian, mengadakan latihan yoga bersama, dan lain sebagainya. Pengembangan produk sesuai dengan permintaan pasar merupakan hal yang sangat umum terjadi pada industri termasuk industri pariwisata. Permintaan yang kebetulan sama dengan potensi yang dimiliki, kemudian, menjadi trend pengembangan produk, karena ketersediaan potensi yang dimiliki oleh sebuah destinasi wisata.

Bali sebagai destinasi wisata budaya bagi kebanyakan wisatawan adalah untuk mengetahui dan mempelajari budaya Bali secara sepintas melalui melihat situs-situs budayanya, menyaksikan ritual yang secara kebetulan didapatinya ketika melakukan perjalanan keliling pulau atau 
menonton keseniannya. Tetapi bagi beberapa wisatawan minat khusus, mereka dengan sengaja datang ke Bali atas dasar tujuan tertentu seperti melakukan upacara pernikahan di Bali dan dilaksanakan secara adat Bali. Motivasi wisatawan dari keinginan melihat sesuatu (something to see), melakukan sesuatu (something to do), dan kemudian membeli sesuatu (something to buy) sepertinya berkembang ke mengalami sesuatu seperti masyarakat lokal (to experience or to be). Wisatawan tidak hanya datang ke Bali dan melakukan pernikahan di Bali dengan tradisinya tetapi mereka ingin merasakan seperti orang Bali. Permintaan ini tentu sangat mudah dipenuhi karena ketersediaan potensi baik material maupun sumber daya manusianya serta peran serta masyarakat lokal dalam mendukung permintaan ini.

Permintaan wisatawan tersebut erat kaitannya dengan otentisitas yang, kemudian, menuntut terjadinya komodifikasi pada kebudayaan lokal. Seperti yang dijelaskan oleh Meethan bahwa komodifikasi bukanlah isu yang terpisah dari pariwisata, tetapi justru merupakan isu sentral terutama dalam pengembangan pariwisata budaya. Komodifikasi sendiri bukan merupakan hasil dari permintaan wisatawan saja, tetapi terkadang budaya wisatawan sendiri berubah karena dampak produk budaya yang tersedia. Otentisitas dan komodifikasi merupakan dua hal yang tidak dapat dipisahkan dengan perubahan minat wisatawan (Meethan, 2002 dalam Smith and Robinson, 2006: 176-179)

Paket wisata Wedding Tradisional Hindu di Bali mungkin saja diikuti oleh wisatawan dengan latar belakang kebudayaan yang sama atau berbeda. Produk ini, kemudian, menjadi sensitif dengan isu-isu penodaan dan penistaan agama yang sekarang sedang ramai dibicarakan di Indonesia. Kasus pernikahan Joe Tully dan Tiko Mulya yang dilakukan di sebuah hotel berbintang di Kawasan Wisata Ubud mengundang reaksi banyak pihak tidak hanya pada masyarakat pendukung kebudayaan Hindu, tetapi juga tokoh-tokoh agama lain di Indonesia. Kontroversi tersebut disebabkan oleh pernikahan yang dilakukan adalah pernikahan sesama jenis (laki-laki) dan menghadirkan seorang pendeta (pemangku) yang mengisyaratkan bahwa perkawinan tersebut dilakukan dengan budaya Bali (Hindu). Aktivitas ini bahkan disebut-sebut sebagai penistaan agama dan melanggar hukum. Theresia Karo-Karo "Heboh Foto Pernikahan Sesama Jenis di Bali” (2015:1). Available from: www.jawaban.com/read/article/id/2015/09/22/92/150922103927. (diunduh tanggal 20 Desember 2016).

Pemahaman tentang agama dan budaya Hindu di Bali menjadi sangat penting untuk dikuasai agar hal-hal tersebut tidak terjadi. Tetapi, masalah penyediaan jasa wedding tradisional Hindu Bali ini terselenggara akibat peran beberapa pihak di destinasi sebagai tuan rumah seperti masyarakat lokal, dan industri. Oleh karena itu, sangat menarik untuk mengkaji komodifikasi ritual perkawinan Hindu pada paket wisata wedding ini dari sudat pandang tuan rumah sebagai penyedia jasa. Atas dasar latar belakang tersebut maka sebuah artikel hasil penelitian yang berjudul "Peran Stakeholder Pariwisata dalam Komodifikasi Ritual Perkawinan Hindu pada Paket Wisata Wedding di Kawasan Wisata Ubud"

\section{Pembahasan}

Konsep sangat penting untuk memberi bingkai pemahaman yang sama pada pembaca tentang terminologi yang digunakan dalam topik yang sedang dibahas. Beberapa konsep yang terkait dengan tema peran stakeholder pariwisata dalam komodifikasi tradisi perkawinan Hindu Bali dalam Wisata wedding diantaranya adalah, konsep stakeholder pariwisata, Komodifikasi, dan konsep Tradisi.

Swarbrook (1999:85) menyebutkan ada 6 pelaku kunci dalam mensukseskan pembangunan pariwisata berkelanjutan :

1. The public sector

2. The tourism industry

3. Voluntary sector organizations

4. The host community

5. The media

6. The tourist

Keenam pelaku kunci itu tidak bisa dipisahkan satu dengan yang lainnya dan itu ada di kedua negara baik di generating country maupun destination country. Pemerintah memegang peranan penting untuk menjadi regulator, karena merekalah yang memegang kebijakan arah pembangunan. Namun betapapun bagusnya kebijakan yang dibuat oleh pemerintah tanpa dukungan stakeholder lainnya tentu tidak akan berarti apa-apa karena kajian yang dilakukan harus melalui pendekatan SHIP yaitu Sistemic, Holistic, Interdisciplinary, dan Participatory. Pariwisata harus dilihat sebagai sebuah sistem yang terintegrasi antara satu komponen dengan komponen lainnya. Holistik adalah pendekatan kajian pariwisata yang bersifat menyeluruh tidak dapat 
dilakukan parsial. Interdisciplinary artinya melibatkan berbagai disiplin ilmu, dan Participatory berarti pendekatan keterlibatan langsung dalam aktivitas pariwisata yang dikaji.

Wisatawan yang datang dengan perbedaan budaya mungkin akan menyumbang dampak negatif di samping dampak positif, karena itu pemerintah di Negara asal juga memegang peranan penting dalam memberikan pemahaman bagi masyarakatnya yang akan berkunjung ke Negara lain agar dapat menghormati budaya dan kearifan lokal. Pemerintah di Negara tujuan wisata juga harus mendidik masyarakatnya agar mewaspadai dampak negatif dari permintaan wisatawan agar jangan membangun pariwisata hanya berdasarkan atas permintaan semata tanpa memperhatikan dampak negatif terhadap alam, masyarakat, dan budaya lokal. Dalam bagan bisa digambarkan sebagai berikut:

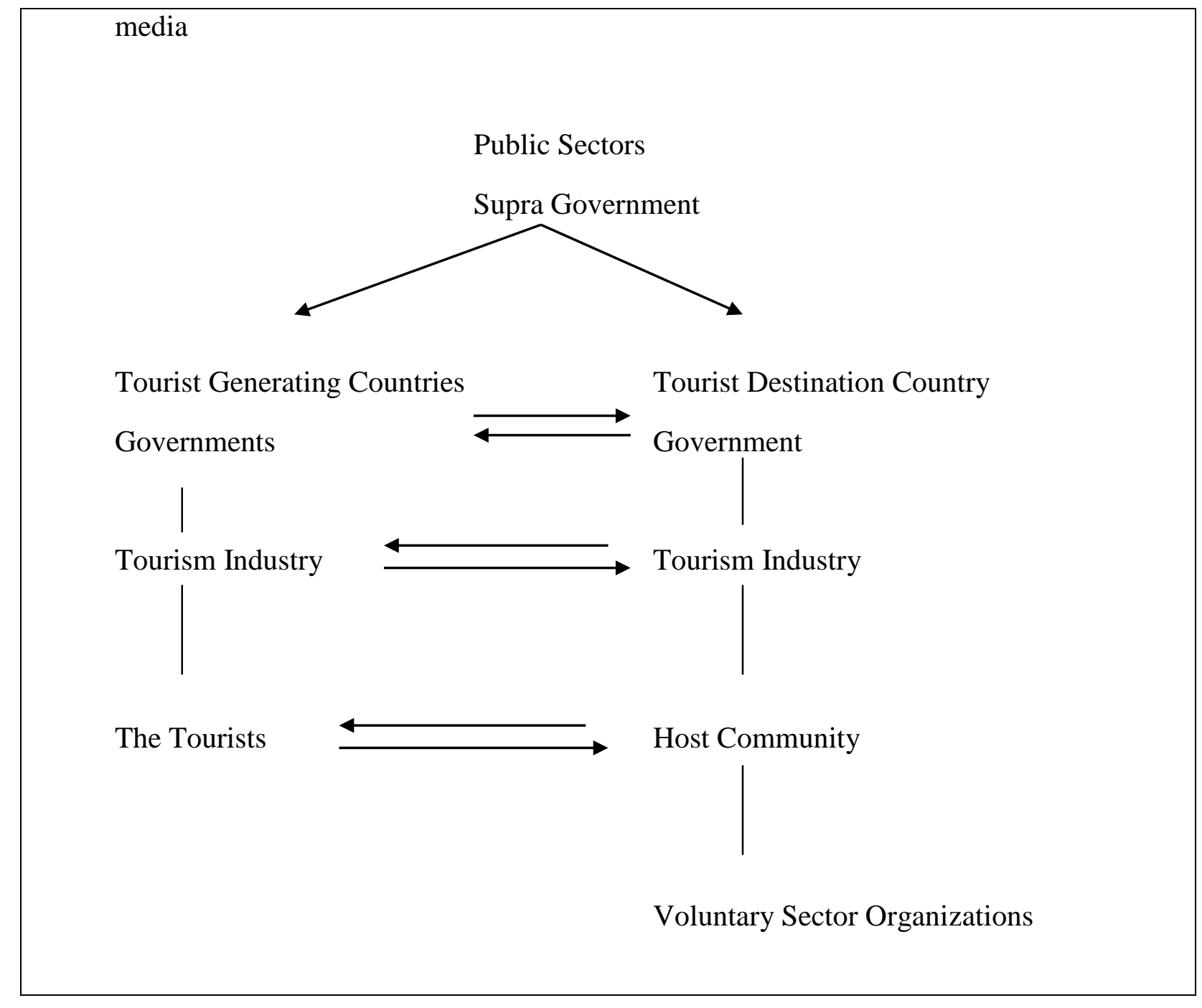

\section{Bagan 1 \\ Diagram Kerjasama Aktor Kunci Pariwisata Berkelanjutan} Sumber: Diolah dari Swarbrook (1999:85).

\section{Tradisi Perkawinan Hindu}

"Tradisi berarti segala sesuatu yang disalurkan atau diwariskan dari masa lalu ke masa kini" dalam arti sempit menurut Sztompka "Tradisi" merupakan kumpulan benda material dan gagasan yang diberi makna khusus yang berasal dari masa lalu. Tradisi lahir melalui dua cara yaitu (1) muncul dari bawah dengan melibatkan masyarakat banyak dengan cara spontan dan tidak diharapkan. Contoh kemunculan tradisi seperti ini dapat dimulai dari kekaguman individu terhadap sebuah temuan yang kemudian disebarkan melalui berbagai cara dan mempengaruhi masyarakat banyak dan dalam perkembangannya berubah menjadi sebuah ritual atau upacara yang diterima masyarakat luas dan menjadi fakta sosial. (2) Tradisi dapat muncul dari atas melalui mekanisme paksaan. Kemunculan tradisi ini biasanya diawali oleh tokoh yang sangat berpengaruh dan berkuasa misalnya seorang raja pada rakyatnya, seorang panglima kepada tentaranya, atau seorang diktator pada rakyat jajahannya. (Shils dalam Sztompka,2012:70).

Tradisi perkawinan Hindu Bali merupakan sebuah tradisi yang sesuai dengan definisi yang pertama. Perkawinan tradisional Hindu Bali merupakan sebuah tradisi yang menjadi identitas dan kebanggaan masyarakat Bali dan dalam perkembangan berikutnya menjadi kebanggaan 
masyarakat konsumen. Bali sebagai daerah tujuan wisata internasional tidak dapat terlepas dari perubahan yang datang akibat permintaan wisatawan. Tradisi perkawinan Hindu Bali, kemudian diterima sebagai tradisi yang dapat dialami oleh masyarakat internasional dan menjadi fakta sosial bahwa tradisi ini pun hidup di industri pariwisata.

\section{Komodifikasi}

Komodifikasi adalah sebuah proses menjadikan sesuatu dari bukan komoditi menjadi komoditi atau bahan dagangan yang bisa dipertukarkan dengan uang, pada umumnya, Piliang (2011:255). Lucas dalam Bukunya History and Class Consciousness menguraikan bahwa kapitalisme menguasai berbagai dimensi kehidupan manusia. Dalam dimensi budaya, manusia mulai memperhitungkan nilai tukar kebudayaan dengan materi. Makna berkebudayaan yang otentik dari sekelompok masyarakat telah memudar dan digantikan dengan perhitungan logis, untung-rugi, dari pertukaran nilai uang dengan sebuah tindakan kebudayaan, inilah yang disebut dengan proses komodifikasi, Sutrisno dan Putranto, (2005:28).

Cohen, Erick (1988:371-386) dalam jurnal penelitiannya menemukan bahwa pariwisata modern telah menimbulkan berbagai perubahan yang berhubungan dengan komoditisasi kebudayaan otentik masyarakat lokal. Komoditisasi tersebut dapat diformulasikan menjadi tiga yaitu:

1. Pariwisata menimbulkan "komoditisasi" pada kehidupan masyarakat di daerah dimana pariwisata merupakan sektor mayoritas. Kebudayaan lokal merupakan contoh yang paling umum dan prinsip yang disajikan sebagai contoh dari terjadinya proses komoditisasi. Secara lebih spesifik contoh contohnya adalah berbagai warna-warni pakaian dan kebiasaan tradisional, ritual dan pesta, serita rakyat dan kesenian etnik menjadi produk yang disajikan untuk pariwisata. Pariwisata dapat merubah makna dari tradisi kebudayaan dan hubungan sosial masyarakatnya.

2. Komoditisasi merusak otentisitas produk kebudayaan lokal dan hubungan antar manusianya. Produk budaya lokal semakin kehilangan makna bagi masyarakat lokal dan lebih penting menyajikannya sebagai budaya "pertunjukan" pada wisatawan dan bahkan tradisi tersebut dihias dengan berlebihan sehingga kelihatan betul-betul tradisional. Masyarakat berpura-pura menjadi dan menjalani kehidupan tradisinya yang otentik, tetapi itu merupakan sebuah tindakan pura-pura yang dapat dikatakan dengan mempermainkan yang asli "to play the native".

3. Otentisitas panggung "staged othenticity' telah menyebabkan kegagalan harapan wisatawan untuk betul-betul merasakan dan mengalami kebudayaan etnik lokal karena sesungguhnya produk budaya etnik yang dipertunjukan untuk konsumsi wisatawan sudah diseting sedemikian rupa sehingga kelihatan asli dari depan sampai ke belakang. Hasilnya adalah timbulnya kesadaran wisatawan bahwa apa yang dikonsumsinya adalah memang kebudayaan otentik, padahal tidak ada kebudayaan otentik yang disajikan untuk wisatawan. Keinginan wisatawan untuk mengalami kebudayaan otentic menurut MacCannell (1973:597) dalam Cohen, (1988:372) merupakan perwujudan modern dari ziarah keagamaan sehingga pariwisata kelihatan menjadi pengganti agama modern.

\section{Kawasan Wisata Ubud}

Kawasan Pariwisata menurut Peraturan Daerah Provinsi Bali Nomor 10 Tahun 2015 tentang Rencana Induk Pembangunan Kepariwisataan Daerah Provinsi Bali Tahun 2015-2029 didefinisikan sebagai kawasan strategis pariwisata yang berada dalam geografis satu atau lebih wilayah administrasi desa/kelurahan yang di dalamnya terdapat potensi daya tarik wisata, aksesibilitas yang tinggi, ketersediaan fasilitas umum dan fasilitas pariwisata serta aktivitas sosial budaya masyarakat yang saling mendukung dalam mewujudkan kepariwisataan.

Kawasan Pariwisata Ubud kemudian menjadi salah satu kawasan wisata dari 16 kawasan pariwisata yang ditetapkan yang mencakup wilayah 3 kecamatan yaitu Kecamatan Ubud, Kecamatan Tegalalang, dan Kecamatan Payangan. Sebaran wilayah kelurahan dan desa tersebut dapat ditunjukan dengan tabel berikut: 
Tabel. 1

Kawasan Wisata Ubud Kabupaten Gianyar

\begin{tabular}{|c|l|l|c|}
\hline No. & Wilayah Kecamatan & Desa/Kelurahan & Luas (Ha) \\
\hline 1. & Ubud & Ubud & 732 \\
\hline & & Kedewatan & 435 \\
\hline & & Peliatan & 493 \\
\hline & & Mas & 465 \\
\hline & & Petulu & 233 \\
\hline & & Lod Tunduh & 627 \\
\hline & & Sayan & 578 \\
\hline & & Singakerta & 675 \\
\hline 2. & Payangan & & 487 \\
\hline & & Melinggih Kaja & 462 \\
\hline & & Melinggih Kelod & 1.291 \\
\hline & & Puhu & 452 \\
\hline 3. & Tegalalang & Kliki & 782 \\
\hline & & Tegalalang & 7.712 \\
\hline & Total & 13 & \\
\hline
\end{tabular}

Sumber: Perda Provinsi Bali Nomor 10 Tahun 2015

Kawasan Pariwisata Ubud mencakup 13 Kelurahan/Desa yaitu 8 Desa berada di Kecamatan Ubud mencakup (1) Kelurahan Ubud, (2) Desa Peliatan, (3) Desa/Kelurahan Mas, (4) Desa Petulu, (5) Lod Tunduh, (6) Desa Sayan, (7) Desa Sayan, (8) Desa Singakerta; 3 Desa berada di Kecamatan Payangan yaitu (1) Desa Melinggih Kaja, (2) Desa Melinggih Kelod, dan (3) Desa Puhu ;2 desa di Kecamatan Tegalalang yaitu (1) Desa Keliki, dan (2) Desa Tegalalang.

Penelitian ini menggunakan metode penelitian Kualitatif dengan teknik pengumpulan data survei dan wawancara mendalam. Lokus penelitian adalah Kawasan Wisata Ubud dengan jumlah populasi ditentukan secara purposive sampling yang berarti hanya objek dan subjek yang dianggap memiliki potensi penyelenggaraan wisata wedding tradisional Hindu Bali yang dijadikan sampel.

Ada dua Teori yang digunakan untuk mengkaji pemanfaatan tradisi perkawinan Hindu Bali sebagai daya tariki wisata yaitu Teori Sistem dan Teori Komodifikasi.

\section{Teori Sistem}

Pada Tahun 1930-an Parson dan kawan2nya mengembangkan Teori yang berusaha merangkum semua unsur tindakan dan masyarakat yang dikenal dengan Teori Umum dengan mengemukakan tiga sistem masyarakat yaitu sistem sosial, kepribadian, dan sistem budaya. (Sutrisno, Muji.2005:59). System dalam penelitian ini termasuk ke dalam sistem budaya yang memiliki preposisi bahwa orang bisa saling berkomunikasi dan mengordinasikan tindakantindakannya dengan cara mempertahankan ekspektasi peran. Ada tiga wilayah penerapan sistem ini yaitu: (1) ranah simbol kognitif yang berhubungan dengan keyakinan tentang dunia dan lain sebagainya, (2) ranah simbol ekspresif yang berhubungan dengan emosi, rasa, estetika termasuk seni di dalamnya, dan (3) standar dan norma moral yang berhubungan dengan nilai-nilai benar dan salah yang disepakati oleh masyarakat.

Teori sistem, kemudian, terus berkembang dan disempurnakan dan lahirlah model AGIL yang merupakan singkatan dari Adaptation, Goal Attainment, Integration, Latern pattern maintenance and tension management). Model ini merupakan kombinasi antara unsur-unsur atau kebutuhan budaya dan material sehingga bersifat multidimensi. Teori ini digunakan untuk mengkaji Tradisi perkawinan Hindu Bali yang dimanfaatkan sebagai Komoditi pariwisata. Tentu yang menjadi subjek analisis adalah tindakan berbagai aktor yang terlibat dalam komodifikasi tersebut. Masyarakat Hindu Bali sebagai pendukung yang memiliki organisasi yang keagamaan yang diharapkan mampu menjaga nilai-nilai dan norma-norma tetap dihormati oleh semua pihak yang terlibat juga dibahas.

\section{Teori Komodifikasi}

Komodifikasi adalah proses menjadikan sesuatu menjadi komoditas. Tradisi perkawinan Hindu Bali yang sebenarnya bersifat sakral dan tidak menjadi barang komodity akhirnya menjadi komoditas pariwisata budaya karena peran berbagai sub-sistem yang saling ketergantungan antar 
satu pihak dan pihak lainnya. Setiap pihak memerankan tindakan kearah komodifikasi karena tujuan masing-masing.

\section{Hasil Analisis Data}

Pihak-pihak yang terlibat dalam komodifikasi ritual perkawinan Hindu dalam Ilmu Kepariwisataan disebut dengan Aktor Kunci Pariwisata. Ada enam pihak yang terlibat dan memerankan peran masing-masing sesuai dengan kapasitasnya yaitu:

\section{Peran Wisatawan}

Wisatawan merupakan pengguna jasa dari berbagai produk dan atraksi wisata yang ditawarkan di sebuah destinasi wisata. Mereka memiliki berbagai tipe yang membawa atau membuat mereka tertarik untuk datang dan mendapatkan pengalaman yang berbeda-beda di setiap destinasi wisata yang dikunjunginya. Dalam penelitian ini, ditemukan beberapa motivasi wisatawan yang mengikuti ritual perkawinan Hindu Bali, seperti adanya keinginan wisatawan untuk mengalami tradisi lokal di daerah kunjungan wisata, beberapa wisatawan ingin mengalami sesuatu yang berbeda tanpa pemaknaan seperti yang dimiliki oleh tradisi itu sendiri, dan ada yang memang memiliki dasar keyakinan untuk dapat manfaat dari pengalaman tradisi yang dianggap sakral oleh masyarakat lokal.

Motivasi wisatawan yang irasional ini sering kali memaksa masyarakat lokal dan pelaku pariwisata lainnya untuk memenuhi dan menyediakan jasa yang diinginkan oleh wisatawan. Wisatawan yang memiliki latar belakang kebudayaan yang berbeda sering kali tidak mengerti dan memahami bahwa tradisi tersebut bersifat sakral dan mereka pun menganggap tradisi tersebut tidak berbeda dengan atraksi wisata budaya yang mereka alami di berbagai destinasi wisata dunia lainnya. Permintaan wisatawan yang disertai dengan kemampuan atau daya beli yang tinggi membuat mereka lupa bahwa mereka harus menghormati budaya masyarakat lokal pada DTW yang dikunjunginya.

\section{Peran Industri Pariwisata}

Industri yang terlibat dalam komodifikasi ritual perkawinan Hindu memiliki keterkaitan satu sama lainnya sebagai sebuah sistem sesuai dengan proses pengambilan keputusan oleh wisatawan seperti:

\section{Travel Agent}

Travel agent sebagai penyedia jasa perjalanan wisata selalu mengembangkan produk layanannya sesuai dengan permintaan dan juga potensi yang dimiliki destinasi wisata. Wisata wedding tradisional di sebuah destinasi yang memiliki kearifan budaya tradisional memiliki daya tarik tersendiri bagi wisatawan. Pencarian tentang otentisitas dari sebuah destinasi dapat ditemukan dengan mudah walau dalam pemenuhan keinginan wisatawan untuk ikut mengalaminya berbeda di suatu destinasi dengan destinasi lainnya. Wedding tradisional Bali, memiliki potensi dikemas menjadi sebuah produk pernikahan utuh atau parsial. Utuh dalam arti wisatawan melakukan wisata wedding sesuai dengan tradisi Hindu Bali dari perspektif tattwa, susila, dan upacara. Tattwa; wisatawan disuguhkan dengan sistem keyakinan dan filsafat makna sebuah perkawinan yang bersifat sakral. Susila; wisatawan disuguhkan pengalaman prosesi ritual perkawinan Hindu Bali dari tata cara berbusana perkawinan tradisional, proses pernikahan, serta sikap dan etika pasangan pengantin Hindu Bali. Upacara; yang berarti wisatawan disuguhkan dengan alat-alat upakara dan proses ritual seperti yang dilakukan oleh Umat Hindu Bali seperti penggunaan sarana upakara, simbol-simbol keagaman, serta melibatkan orang suci atau pemangku sebagai perantara dan pemimpin ritual perkawinan tersebut. Secara parsial yang dimaksud bahwa wisatawan dapat mengalami tradisi pernikahan secara terpisah, misalnya memakai pakaian adat pernikahan, melakukan dokumentasi atau foto prewedding seperti masyarakat Hindu Bali, dsbnya.

Berdasarkan pengamatan di industri, travel agent memanfaatkan potensi ini untuk mengkemas ritual perkawinan Hindu menjadi daya tarik wisata. Travel agent mengembangkan departemen khusus yang menangani masalah pasar wisatawan wedding dengan membentuk wedding organizer (WO) sebagai bagian dari departemen yang dimilikinya. WO ini merupakan tambahan sejak meningkatnya minat wisatawan wedding yang sebelumnya dianggap tidak begitu banyak memberikan keuntungan bagi perusahaan. Sebelum departemen WO ini berkembang, pasar wisatawan berkelompok 
ditangani oleh sebuah departemen yang disebut dengan MICE yang merupakan singkatan dari meeting, incentive, conference, dan exibition. Departemen tersebut menangani wisatawan yang mengadakan pertemun, yang beberapa digabungkan dengan kegiatan karyawan sebuah perusahaan yang diberi insentif wisata, konferensi, serta pameran.

Wedding organizer dikelola secara terpisah disebabkan oleh karakteristik wistawan dan juga jasa yang sangat berbeda dengan kharakter jasa perjalanan pada umumnya. Wisata ini melibatkan beberapa orang yang memang mengerti masalah pernikahan sehingga kelompok ini merupakan kelompok profesionals yang dapat berkordinasi dan berkomunikasi dengan baik dengan masyarakat lokal termasuk pendeta dan ahli upakara.

2. Hotel

Hotel bertugas menyediakan berbagai jasa layanan wisatawan yang menginap selain kamar, hotel juga menyediakan jasa makanan, minuman, binatu, tempat parkir, dan sarana hiburan lainnya. Permintaan wisatawan akan ritual pernikahan yang meningkat membuat hotel juga menyediakan fasilitas serupa seperti yang terlihat pada Gambar 1 . Berikut. Sebuah anjungan di tepi Sungai Ayung dengan latar belakang pemandangan sungai dan hutan tropis dirancang oleh Hotel Kupu-Kupu Barong di Kawasan Wisata Ubud. Dengan fasilitas seperti ini tentu memudahkan bagi wisatawan untuk melaksanakan perkawinannya di sebuah hotel dan mendatangkan semua peralatan dan perlengkapan upacaranya. Hotel ini pun menyediakan suasana tradisional Hindu Bali dengan memasang penjor dan pejeng yang biasanya digunakan pada saat ritual keagamaan Hindu di Bali.

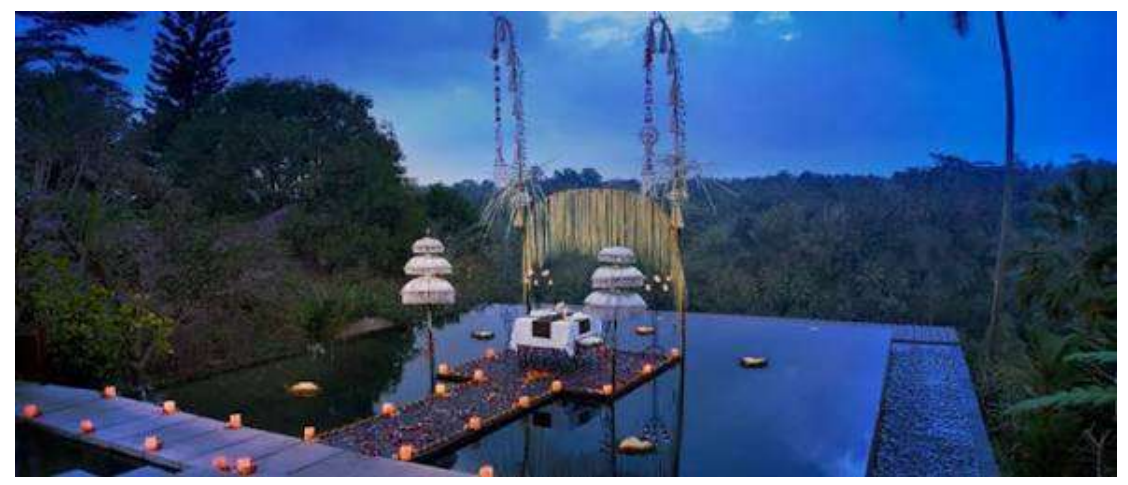

Gambar 1

Anjungan Perkawinan di Kupu-Kupu Barong

\section{Restoran}

Restoran dan penyedia jasa makanan lainnya juga mendukung setiap aktivitas wisata yang menyajikan tema tradisional dengan membuat setting tradisi dan jamuan makan tradisional Bali bagi wisatawan yang melaksanakan resepsi pernikahan tradisional Bali.

4. Wedding Organizer

Wedding Organizer memanfaatkan potensi yang dimiliki oleh budaya lokal di setiap destinasi wisata budaya untuk memenuhi permintaan wisatawan akan pengalaman tentang otentisitas. Seperti yang disebutkan dalam pendahuluan artikel ini, bahwa di Thailand juga terjadi pernikahan wisatawan dengan ritual tradisi Thailand lengkap dengan Biksunya. Balim memiliki berbagai keunikan yang ditunjukan oleh tradisinya yang memiliki karakteristik otentik Bali dari busana tradisional, musik tradisional, ritual tradisional dengan pendeta atau pemangu yang merepresentasikan kebalian dan kehinduan. Wedding organizer memanfaatkanini sebagai sebuah produk untuk pangsa pasar wisatawan yang menginginkan pengalaman yang unik pada acara perkawinan.

5. Industri Budaya lainnya

Industri budaya tidak hanya memproduksi kerajinan dan produk budaya lainnya yang dapat dibeli oleh wisatawan sebagai cinderamata. Industri budya profan merupakan industri budaya yang umum dikenal mendukung industri pariwisata. Tetapi industri budaya sakral yang memproduksi sarana keagamaan mungkin belum pernah terbayangkan ntuk wisatawan. Tetapi permintaan wisatawan yang irasional membuat semuanya mungkin. Komodifikasi ritual perkawinan yang bersifat sakral dan pada awalnya tidak diperuntukan untuk wisatawan, akhirnya diperjualbelikan untuk kebutuhan wisata ini. Sarana upacara yang bersifat sakral, simbol-simbol keagamaan Hindu seperti umbul-umbul, dan pajeng serta yang lainnya digunakan untuk aktivitas wisata sesuai dengan keinginan wisatawan. 


\section{Peran Masyarakat Lokal}

Masyarakat lokal yang dimaksud dalam penelitian ini adalah masyarakat pemilik atau pendukung kebudayaan Hindu yang memiliki ritual perkawinan sebagai daya tarik wisata. Masyarakat lokal yang terlibat dalam komodifikasi ritual perkawinan Hindu adalah Pemangku, serati banten, dan masyarakat biasa. Masyarakat Bali merupakan masyarakat yang sangat permisif dan bersifat terbuka pada wisatawan. Hal ini dapat dilihat dengan partisipasinya dalam aktivitas komodifikasi ritual perkawinan Hindu yang sesungguhnya bersifat sakral menjadi komoditi dalam industri pariwisata. Pada beberapa aktivitas wisata wedding yang diselenggarakan oleh industri kepariwisataan terlihat jelas bahwa pemangku yang disucikan dan bertugas dalam mengampu kegiatan-kegiatan keagamaan menjadi salah satu aktor dalam proses komodifikasi baik sebagai saksi atau pengantar ritual maupun sekedar sebagai latar belakang sesi pengambilan photo pranikah atau photo wedding. Pemangku, dalam masyarakat Hindu Bali, memiliki status sosial religious yang tinggi, hal ini dibuktikan dengan tingkatan bahasa (Bahasa Bali) yang digunakan masyarakat Hindu Bali pada saat berkomunikasi dengannya yang menggunakan Bahasa Bali alus.

\section{Peran Pemerintah}

Pemerintah dalam sistem pariwisata adalah salah satu dari enam aktor kunci pariwisata yang berperan sebagai pembuat kebijakan (role maker). Pemerintah sebagai sektor publik berperan mengatur jalannya bisnis pariwisata melalui peraturan-peraturan baik di tingkat Undang-undang dan Peraturan perundang-undangan di bawahnya. Lokus penelitian ini adalah Kawasan Wisata Ubud yang berada di wilayah Kabupaten Gianyar. Berdasarkan studi kepustakaan dan wawancara dengan pihak pemerintah, dalam hal ini dinas pariwisata Kabupaten Gianyar, tidak terdapat aturan khusus yang mengatur tentang jenis wisata perkawinan adat Bali.

\section{Peran Lembaga Keagamaan Hindu}

Salah satu aktor kunci pariwisata yang biasanya ada pada posisi kontrol adalah organisasi non-pemerintah (non-government organization) yang di Indonesia dikenal dengan istilah Lembaga Swadaya Masyarakat (LSM). Lembaga yang erat hubungannya dengan ritual perkawinan Hindu adalah lembaga keagamaan yaitu Parisada Hindu Dharma Negeri Indonesia-Bali (PHDI-Bali). Lembaga ini berwenang dalam memberikan penyuluhan dan pelurusan terhadap hal-hal yang menyimpang dari ajaran Agama Hindu. Lembaga ini juga berwenang membuat aturan dalam hal pelaksanaan kehidupan beragama termasuk melaksanakan ritual perkawinan Hindu.

\section{Peran Media}

Eksistensi media sebagai sarana komunikasi dan promosi memegang peranan yang sangat penting dalam pemasaran produk pariwisata. Media yang sudah berkembang dari media cetak seperti koran, majalah, tabloid, serta buku-buku khususnya yang memuat konten pariwisata sampai media elektronik seperti radio, televisi, serta media internet yang sangat cepat dan mudah diakses pada daerah-daerrah yang sudah memiliki jaringan internet. Promosi ini menyebabkan segala jenis produk pariwisata yag baru dapat diketahui dengan cepat oleh wisatawan dan juga penyampai jasa, sehingga proses mengamati, meniru, dan kemudian memodifikasi produk bagi pengguna jasa dan menikmati produk alternatif secara dini oleh wisatawan dapat berlangsung dalam waktu yang sangat singkat.

Media informasi sangat berperan dalam pengembangan wisata wedding yang diselenggarakan di Bali dengan tradisi adat Hindu Bali. Dalam desk research yang dilakukan ada dua kali isu tentang perkawinan yang dilakukan oleh sesama jenis. Perkawinan pertama dilakukan oleh Joshua dalam sebuah berita yang terjadi pada bulan September 2009 di sebuah resort mewah di Ubud. Kejadian tersebut sebenarnya telah menjadi topik hangat yang dibahas dalam majalah TripAdvisor for Android available from http://www.tripadvisor/ShowTopic-g2942226-i7220k3088828-Gay_Wedding_in-Bali_Bali.html [cited on july 20, 2017]. Tetapi tidak ada tanggapan serius dari pemerintah Provinsi Bali dan juga organisasi keagamaan baik pemerintah (Kementerian Agama Provinsi Bali dan Kabupaten Kota) maupun organisasi masyarakat di luar kepemerintahan (Parisada Hindu Dharma).

Dalam diskusi tersebut diungkapkan bahwa seorang wisatawan yang mengetahui upacara pernikahan sesama jenis tersebut menganggap hal tersebut tidak akan mendapat reaksi keras dari masyarakat Bali. Hal ini disebabkan oleh karena masyarakat Bali bersifat sangat terbuka dan nerima keberadaan gay di lingkungannya. Dalam postingannya pemilik akun yang bernama "ryzee" mengungkapkan keheranannya dengan kondisi yang sangat kondusif dengan keberadaan gay sehingga upacara perkawinan sepasang gay laki-laki berjalan dengan lancar, padahal 
komunitas gay ini sangat membenci sebuah tempat yang memiliki tingkat antigay walau hanya 1\%. Tetapi Bali menurut beberapa komentar dalam group tersebut dikatakan sangat menerima keberadaan gay yang dapat dilihat dengan keberadaan fasilitas penunjang pariwisata seperti yang berada pada kawasan wisata Legian.

Peristiwa yang sama terjadi lagi pada tahun 2015. Pernikahan sesama jenis tahun ini melibatkan seorang warga Amerika dan seorang warga Indonesia. Foto yang tersebar luas dengan dua orang laki-laki berdiri berhadapan di depan seorang yang berpakaian seperti seorang pendeta Hindu (pemangku) menjadi firal di media masa termasuk dimuat di media luar negeri. Dalam salah satu berita yang dimuat News Corp Australia Network dengan headline "Controversy after the gays got marriage in Bali" diberitakan bahwa pemerintah (Gubernur Bali) bereaksi keras atas peristiwa ini dan mengatakan bahwa pernikahan sesama jenis tersebut tidak dibenarkan menurut hukum Hindu dan juga menurut Hukum positif Indonesia. Berita juga memuat bahwa Kepolda Bali juga mengadakan investigasi tentang identitas mempelai, tempat upacara pernikahan, dan orang-orang yang menyaksikan serta terlibat dalam upacara pernikahan seperti yang terlihat pada foto yang tersebar di media sosial. "Controversy after the gays got marriage in Bali" available from http://www.news.com.au-asia-news-story [cited on June, 22 2017]

Peran media sebagai kontrol sosial, dalam kasus ini, berjalan efektif hal tersebut dapat dilihat dengan reaksi dari asosiasi organisasi penyelenggara pernikahan di Bali yang mulai mensosialisasikan UU perkawinan No.1 Tahun 1974 untuk legalitas sebuah perkawinan dalam situs yang dimilikinya. Seperti yang dimuat oleh Bali Wedding Organizer yang memuat beberapa persyaratan sebagai berikut:

1. Perkawinan diselenggarakan oleh pasangan yang berlainan jenis

2. Perkawinan diselenggarakan secara tradisi keyakinan mempelai

3. Perkawinan diselenggarakan atas persetujuan pasangan sebelumnya

4. Dsb.nya.

Beberapa aturan tersebut membuat standar bagi Wedding Organizer untuk tidak sembarangan menggunakan atribut keagamaan dalam melaksanakan upacara perkawinan yang melibatkan mempelai yang bukan beragama Hindu. Karena hal tersebut merupakan tindakan melawan hukum dan dapat dikenakan sanksi pidana pelecehan atau penistaan agama.

\section{Penutup}

Paket wisata wedding secara umum memberikan dampak positif terhadap pendapatan masyarakat lokal, yang dalam hal ini pihak-pihak yang terkait dengan paket wisata wedding. Paket wisata ini juga menambah daya tarik wisata budaya Bali sebagai daya tarik wisata minat khusus dimana wisatawan memang sengaja datang ke Bali untuk melakukan hajatan pernikahan. Secara rinci dapat dipaparkan kesimpulan sebagai berikut:

Komodifikasi ritual perkawinan Hindu Bali di kawasan wisata Ubud merupakan sebuah aktivitas wisata hasil dari peran berbagai pihak yang terintegrasi dalam satu kesatuan sistem pariwisata yang utuh dimana masing-masing aktor memberi kontribusi dan saling melengkapi untuk berjalannya aktivitas wisata wedding.

Hasil analisis penelitian ini berujung pada kesimpulan yang selanjutnya menghasilkan saran sebagaimana yang diharapkan dari sebuah penelitian untuk memenuhi unsur aksiologi penelitian. Beberapa saran dapat ditulis sebagai berikut:

1. Bagi Pemerintah, baik Pemerintah Kabupaten Gianyar dan juga Pemerintah Provinsi Bali hendaknya membuat peraturan daerah atau peraturan-peraturan sejenis yang mengatur tentang berbagai pemanfaatan simbol-simbol agama sebagai komoditi pariwisata termasuk wisata pernikahan tradisional Bali. Hal ini untuk memberikan kepastian hukum bagi para penyelenggara dan pengguna jasa perkawinan tradisional Hindu Bali sebagai produk pariwisata.

2. Bagi organisasi non pemerintah, khususnya PHDI-Bali, agar melakukan pembinaanpembinaan terhadap para pelaku pariwisata agar tidak terjadi penodaan agama akibat ketidakpahaman pemanfaatan simbol-simbol agama sebagai komoditi pariwisata. PHDI juga harus membuat teguran terhadap penyimpangan-penyimpangan atau kekeliruan yang dilakukan oleh berbagai pihak yang memanfatkan ritual perkawinan Hindu Bali sebagai komoditi pariwisata.

3. Bagi pelaku atau industri pariwisata, hendaknya berhati-hati dalam memanfaatkan aktivitas-aktivitas keagamaan termasuk perkawinan tradisional Hindu Bali sebagai produk pariwisata sehingga tidak terjadi penodaan agama yang berakibat pada konflik dengan penduduk pendukung keagamaan bersangkutan. 


\section{Daftar Pustaka}

Abdulah, T. dan Karim, R. M. 2004. Metodologi Penelitian Agama; Suatu Pengantar. Yogyakarta: Tiara Wacana.

Adlin, Alfathri. 2007. Spiritualitas dan Realitas Kebudayaan Kontemporer. Bandung. Jalasutra.

Apostolopoulos, Yorghos. 2002. The Sociology of Tourism:Theoretical and Empirical Investigations. Newyork:Routledge.

Ardika, I Wayan.2003.Pariwisata Budaya Berkelanjutan. Denpasar: Program Studi Magister (S2) Kajian Pariwisata Program Pasca Sarjana Universitas Udayana.

Burhanudin, J. Dan Baedowi, A. 2003. Transformasi Otoritas Keagamaan: Pengalaman Islam Indonesia Jakarta: PT. Gramedia Pustaka Utama.

Burns, M.Peter.1995.Tourism: A New Perspective. London: Prentice Hall.

Conlin, Michael.V. 1995. Island Tourism:Management Princioles and Practice. Newyork:John Willey and Sons.

Daniel L.Pals. 2001. Seven Theories of Religion. Yogyakarta:Penerbit Kalam

Denzin, K. dan Lincoln, S. 2009. Hanbook of Qualitatuve Research. Yogyakarta:Pustaka Pelajar.

Dickens, R.D dan Fontana, A. 1994. Posmodernism and Social Inquiry. New York: The Guilford Press.

Dickman, Sharron. 1992. Tourism: An Introductory Text. London:Edward Arnold.

Devaraja, N.K. 1974. Philosophy, Religon, and Culture. India: Montilal Banarsidas.

Garfinkel, Perry. 2006. Tourists dig deep, travel far, to find their inner selves available from : http://timesfoundation.taipeitimes.com/articleshow/1268804.cms. Ditelusuri pada tanggal 8 April 2012.

Gee, Y. Chucky. 1999. International Tourism, A Global Perspective. Madrid: World Tourism Organization.

Hall, Michael. Dan Weiler, Betty. 1992. Special Interest Tourism. New York: John Willey and Sons.Inc.

Haryanto, Sindung. 2015. Sosiologi Agama:Dari Klasik hingga Postmodern.Yogyakarta:Ar-Ruzz Media.

Ihromi, T.O. 2006. Pokok-pokok Antropologi Budaya. Jakarta: Yayasan Obor Indonesia.

Jagannathan, S. H. 1984. An Introduction to Hinduism. Denpasar: Pustaka Bali Post.

Jennings, Gayle. 2001. Tourism Research.Australia:John Willey and Sons.

Jenks, Chris. 2013.Culture:Studi Kebudayaan. Yogyakarta:Pustaka Pelajar.

Koentjaraningrat. 2005. Pengantar Antropologi; pokok-pokok etnografi II. Jakarta: Rineka Cipta.

Mujib, Ibnu. dan Rumahuru, Yance. Z. 2010. Paradigma Transformatif Masyarakat Dialog;Membangun Fondasi Dialog Agama-Agama Berbasis Teologi Humanis. Yogyakarta: Pustaka Pelajar.

Natori, Masahiko.2001. A Guide Book for Tourism-Based Community Development. Japan: AsiaPacific Tourism Exchange Center (APTEC)

Page, J. Stephen. dkk. 2001. Tourism: A Modern Synthesis. Italy:Thompson Learning.

Peursen, Van.C.A. 1988. Strategi Kebudayaan. Jakarta: Kanisius.

Piliang, Y.A. 2010. Dunia Yang Dilipat, Bandung:Matahari 
Radhakrisnan. S, 2003. Religion and Society. Denpasar: Program Magister Ilmu Agama dan Kebudayaan Universitas Hindu Indonesia.

Richard King. 2001 Agama, Orientalisme, dan Poskolonialisme; sebuah kajian tentang pertelinkahan Antara Rasionalitas dan Mistik. Yogyakarta: Qalam

Ritchie, Brent. J.R. 1994. Travel, Tourism, and Hospitality Research: A Handbook for Managers and Researchers. Colorado:John Willey and Sons.

Ritzer, George. 2007. Teori Sosiologi Modern. Jakarta: Kencana.

Rogers, J. C. 2007. Secular Spiritual Tourism. Australia: Central Queensland University.

Rudyansjah, Tony. 2015. Emile Durkheim:Pemikiran Utamanya dan Percabangannya ke Radcliffe-Brown, Fortes, Levi-Straus, Turner, dan Holbraad. Jakarta: Kompas Penerbut Buku.

Russel, Bertrand. 2009. Bertuhan Tanpa Agama. Yogyakarta:Resist Book.

Saranam, Sankara. 2009 God Without Religion; mempertanyakan kebenaran yang telah diterima selama berabad-abad. Jakarta: PT. Gramedia Pustaka Agama.

Sarbini, Mbah Ben. 2014. Filsafat Pariwisata: Sebuah Kajian Filsafat Praktis. Yogyakarta:PT. Kanisius.

Schiffman, Leon.G. dan Kanuk, Leslie Lajar. 2000. Consomer Behaviour. New Jersey. Prentice Hall International. Inc.

Shane, D. 2008. The Extension of Muslow Theory of Motivation. available from: http://www.simplypsychology.org/maslow.html. ditelusuri tanggal 20 Desember 2012.

Shaw, G. and Williams, A. 1995 Critical Issues in Tourism; A Geographical Perspective. Cambridge USA: Blackwell Publishers.

Shenoy, Mohan. 2008. Minimum Hinduism Practice. Rajastan: Adyar Gopal Parivar.

Simon, Fransiskus.2008. Kebudayaan dan Waktu Senggang. Yogyakarta:Jalasutra.

Smith, Melanie.K. dan Robinson, Mike. 2006. Cultural Tourism in a Changing World:Polotics, Participations, and Representation. Canada: Channel View Publication.

Soekadijo, R.G. 1997. Anatomi Pariwisata; Memehami Pariwisata sebagai systemic linkage. Jakarta:Gramedia.

Sutrisno, Muji dan Putranto, Hendar. 2005. Teori-Teori Kebudayaan. Yogyakarta: Kanisius. 2009. Ranah-Ranah Kebudayaan:dalam Esai. Yigyakarta:Penerbit Kanisius.

Swarbrooke, J. 1999. Sustainable Tourism Management. New York:CABI Publishing.

Sztompka, Piotr. 2012. Sosiologi Perubahan Sosial. Jakarta:Prenada.

Theresia Karo-Karo "Heboh Foto Pernikahan Sesama Jenis di Bali" 2015. Available from: www.jawaban.com/read/article/id/2015/09/22/92/150922103927. [diunduh tanggal 20 Desember 2016]

Tjatera, W. 2006.Perencanaan Pembangunan Daerah Bali Berkelanjutan: sinergi Tujuan Pertumbuhan Ekonomi, Pelestarian Lingkungan dan Budaya. Denpasar : Universitas Udayana.

Titib, I Made. 2003 Teologi dan Simbol-Simbol dalam Agama Hindu. Surabaya:Paramita.

Turner, Bryan.S. 2012. Teori Sosial:dari klasik sampai modern. Yogyakarta:Pustaka Pelajar.

Usman, Sunyoto. 2015. Esai-Esai Sosiologi Perubahan Sosial. Yogyakarta:Pustaka Pelajar.

Yamashita,Shinji.1997.Tourism and Cultural Development in Asia and Oceania: Universiti Kebangsaan Malaysia 
Yoeti, Oka A, 2001.Tours and Travel Management. Jakarta: Pradnya Paramita.'

Weber, Max. 2009. Sosiologi, Yogyakarta:Pustaka Pelajar 